\title{
Effect of Stocking Density on Growth Performance, Production Trait, Food Utilization and Body Composition, of Meagre (Argyrosomus regius)
}

\author{
A. Ghozlan1, M. M. Gaber'1, M. A. Zaki2² , A. Nour² \\ ${ }^{1}$ National Institutes of Oceanography and Fisheries, Cairo, Egypt \\ ${ }^{2}$ Animal Production Department, Alex University, Alexandria, Egypt \\ Email: *gabermagdy@yahoo.com
}

How to cite this paper: Ghozlan, A., Gaber, M.M., Zaki, M.A. and Nour, A. (2018) Effect of Stocking Density on Growth Performance, Production Trait, Food Utilization and Body Composition, of Meagre (Argyrosomus regius). World Journal of Engineering and Technology, 6, 37-47. https://doi.org/10.4236/wjet.2018.63B005

Received: August 10, 2018 Accepted: August 26, 2018 Published: August 29, 2018

\begin{abstract}
A 10-week rearing trial was conducted in cages with average initial weight of $9.15 \pm 0.2 \mathrm{~g} /$ fish and average initial length of $9.2 \pm 0.02 \mathrm{~cm} /$ fish of meagre, Argyrosomus regius, to examine the effect of three stocking density on growth performances, production traits, feed utilization and body composition. Nine cages $24 \mathrm{~m}^{3}$ each $(4 \times 6 \times 1.5 \mathrm{~m}$, long, width and height $)$ were stocked with either 1200, 3600 and 6000 fish for each cage to give a stocking rate of 50,150 , and $250 \mathrm{fish} / \mathrm{m}^{3}$ respectively and fish fed daily, slightly in excess of satiation to eliminate the possibility of food supply being a limiting factor to growth. The results revealed that, mean final weight ( $\mathrm{g} / \mathrm{fish}$ ), gain in weight, SGR (\%per day), feed conversion ratio, protein efficiency ratio and total feed intake ( $\mathrm{g} /$ fish) were significantly $(\mathrm{P} \leq 0.01)$ influenced. The best at the lowest stocking density, while, the total production and net production exhibited significantly the opposite trend. Harvest and production estimates increased with increasing stocking density. Fish body composition\% of moisture, protein, fat and ash were significantly $(\mathrm{P} \leq 0.01)$ influenced by stocking density. From the above results and the economic information of the study, it can be concluded that stocking density of $50 \mathrm{fish} / \mathrm{m}^{3}$ of meagre exhibited the highest net profit and would seem to be the most desirable density in the system studied.
\end{abstract}

\section{Keywords}

Stocking Density, Meagre, Growth, Production, Body Composition 


\section{Introduction}

Meagre (Argyrosomus regius) become the world's largest sciaenid fish that is widely distributed along the eastern Atlantic coast, including the Mediterranean sea as reported by [1]. This species is characterized by domestication ability, high tolerance to wide ranges of salinity $(5 \%-39 \%)$ and temperature $\left(13^{\circ} \mathrm{C}\right.$ $28^{\circ} \mathrm{C}$ ) and exhibits high growth rates reaching $1.2 \mathrm{~kg}$ in less than 2 years. Its quality features include an attractive body shape for selling as whole fish, a good processing yield and nutritional value, low fillet fat, excellent taste and firm texture [1] [2], which distinguish meagre as a highly marketable fish species.

Stocking density is a major factor that affects fish growth under farmed conditions [3] [4]. Increasing stocking density results in stress [5] which leads to enhanced energy requirements causing reduced growth and food utilization. Consequently, identifying the optimum stocking density for a species may be critical factor is affecting growth and feed intake in cages. Fish density is a key factor affecting growth and maturation of wild and cultured fish besides food supply and its quality, genetics and environmental conditions [6] [7]. Rearing fish at inappropriate stocking densities may impair growth and reduce immune competence due to factors such as social interactions and deterioration of water quality, which can affect both feed intake and conversion efficiency of the fish [8].

The major objective were to determine the effects of stocking density on growth performance, food utilization, and finally the economic feasibility of Meagre as species suitable for cages culture in Egypt.

\section{Materials and Methods}

\subsection{Fish and Facilities}

The experiment was carried out at the outdoor of Mount of Diba at Domiate Governorate, Egypt. The experimental system consisted of nine experimental cages. Each of them was $4 \mathrm{~m}$ long, $6 \mathrm{~m}$ width and $1.5 \mathrm{~m}$ height. Water level in the cages was kept at $1 \mathrm{~m}$ depth to maintain the water volume at $24 \mathrm{~m}^{3}$.

A set of 10,800 meagre fingerlings were obtained from Mount of Diba at Domiate Governorate, Egypt. The initial average was $9.14 \pm 0.02 \mathrm{~g} /$ fish and average initial length of $9.2 \pm 0.02 \mathrm{~cm} /$ fish respectively. Cages $24 \mathrm{~m}^{3}$ each were stocked with either 12003600 and 6000 fish for each cage to give a stocking rate of 50, 150 , and $250 \mathrm{fish} / \mathrm{m}^{3}$ with triplicate cages per treatment.

The practical diet formulated to contain $42.74 \%$ crude protein and $5.12 \mathrm{kcal} / \mathrm{g}$ gross energy and covering all nutrient requirements of Meagre (Table 1). In preparing the diet, dry ingredients were first ground to a small particle size (approximately $250 \mu \mathrm{m}$ ) in a Wiley mill. Ingredients were thoroughly mixed and then thoroughly added water to obtain a $30 \%$ moisture level. Diet was passed through a mincer with die into $2.5-\mathrm{mm}$ diameter spaghetti-like strands and was dried under sun for $8 \mathrm{~h}$. after drying the diet was broken up and sieved into appropriate pellet size. Diet was stored at $-20^{\circ} \mathrm{C}$ in plastic lined bags until fish were fed. The fish were fed daily manually, slightly in excess of satiation to eliminate 
Table 1. Feed formulation and proximate composition of diets contained (HBP) feed to Meagre (Argyrosomus regius).

\begin{tabular}{cc}
\hline Ingredients (\%) & Diets \\
\cline { 2 - 2 } Fish meal (C.P.65\%) & AF \\
Soybean meal (C.P.44\%) & 40.0 \\
Yellow corn meal & 20.0 \\
Gluten & 20.0 \\
Fish oil & 10.0 \\
Vit. \& Min premix ${ }^{1}$ & 7.0 \\
Calcium diphosphate & 1.0 \\
Proximate analyses (\%) & 2.0 \\
Crude protein & \\
Crude fat & 42.74 \\
Ash & 17.26 \\
Crude fiber & 8.6 \\
NFE & 1.60 \\
Gross energy Kcal $/ \mathrm{g}^{4}$ & 29.8 \\
P:E ratio (mg CP:kcal) & 5.1 \\
\hline
\end{tabular}

${ }^{1}$ Vitamin and mineral premixed according to [33] Madan, et al. (2009). ${ }^{2}$ Values represent the mean of three sample replicates. ${ }^{3} \mathrm{NFE}-$ Nitrogen Free Extract $=100-(\%$ crude protein $+\%$ crude fat $+\%$ crude ash $+\%$ crude fiber). ${ }^{4}$ The calorific values for protein, fat and carbohydrate was obtained by the conversion factors $5.65,9.45$ and $4.1 \mathrm{kcal} / \mathrm{g}$ respectively.

the possibility of food losses in each cage for 10 weeks. About $25 \%$ of fish in each cage were randomly sampled and measured at 2 weeks intervals for body weight $(\mathrm{W})$ to the nearest $0.1 \mathrm{~g}$. dissolved oxygen $(\mathrm{mg} / \mathrm{L})$ and water temperature ${ }^{\circ} \mathrm{C}$ in all cages were monitored twice daily (0800 and 1430) by means of YSI model 58 oxygen meter. Other water quality parameters including $\mathrm{pH}$, total ammonia $(\mathrm{mg} / \mathrm{L})$ were measured twice weekly in each cage throughout the duration of study (10 weeks), according to [9].

\subsection{Harvest Data and Body Composition}

Fish were not fed 24 hours prior to harvest, the total number and individually weight of all fish in each cage were recorded at harvest. For body composition analysis, 5 fish from each cage at harvest were randomly sampled and stored at $-20^{\circ} \mathrm{C}$ for subsequent chemical analysis. Proximate analysis of the formulated diets and fish carcasses were determined according to standard methodology [10].

\subsection{Statistical Analysis}

Data on growth, feed utilization, survival rate and proximate and chemical composition of whole fish body were subjected to one-way ANOVA [11]. To locate significant differences between fish size within fish meal replacement, the data were analyzed with a one-way ANOVA to obtain the error mean square 
needed for Duncan's multiple rang test [12]. All percentages and ratio were transformed to arcsine values prior to analysis [13].

\section{Results}

\subsection{Water Quality}

During the feeding trial, the water quality parameter were not significantly different $(\mathrm{P} \geq 0.05)$ among treatments: averaged $( \pm S \mathrm{SD})$ : water temperature $27.2^{\circ} \mathrm{C}$ $\pm 0.8^{\circ} \mathrm{C}$ dissolved oxygen $6.8 \pm 0.4 \mathrm{mg} \cdot 1^{-1} ; \mathrm{pH} 7.4 \pm 0.6$; ammonia $\pm 0.04 \mathrm{mg} \cdot 1^{-1}$; nitrite $0.1 \pm 0.05 \mathrm{mg} \cdot \mathrm{l}^{-1}$; nitrate $1.5 \pm 0.2 \mathrm{mgl}^{-1}$; alkalinity $181 \pm 46 \mathrm{mg} \cdot \mathrm{l}^{-1}$; salinity $35.2 \pm 1.1 \mathrm{~g} \cdot \mathrm{L}^{-1}$.

\subsection{Fish Growth and Production}

It has found that the growth of Meagre was affected stocking density. Fish reared at low density grow better than those reared at high density (Table $2 \&$ Figure 1 ), and the differences where highly significantly. Final mean weight were inversely proportional to stocking density, which was particularly evident when average fish weight reared at the lowest stocking density significantly different from fish weight reared at the highest stocking density. It can be concluded from Table 2, mean final weight ( $\mathrm{g} /$ fish), mean final length $(\mathrm{cm} / \mathrm{fish})$, gain in weight specific growth rate (SGR) relative growth rate and survival rate\% were significantly $(\mathrm{P} \leq 0.01)$ the best at the lowest stocking density, while, total production and net production exhibited significantly the opposite trend Table 3. Harvests and production estimate increased with increasing stocking density. At the end of the experiment, total production was $4.57 \mathrm{Kg} / \mathrm{m}^{3}$ at the lowest stocking density and $7.17 \mathrm{Kg} / \mathrm{m}^{3}$ at the highest stocking density. Production was opposite to the individual weight during the growth period, that the individual weight decreased with the increasing stocking density (Figure 2 and Table 3), while total production increased with increasing stocking density.

\subsection{Feed Utilization Efficiency}

The results of feed conversion ratio (FCR), protein efficiency ratio PER), feed intake (FI) condition factor (K), protein productive value and energy utilization

Table 2. Effect of different stoking density on growth performance of Meagre (Argyrosomus regius, Asso1801).

\begin{tabular}{|c|c|c|c|c|c|c|c|c|c|}
\hline \multirow{2}{*}{$\begin{array}{l}\text { Stoking } \\
\text { density }\end{array}$} & \multicolumn{2}{|c|}{$\begin{array}{c}\text { Average body weight } \\
\text { (g/fish) }\end{array}$} & \multicolumn{2}{|c|}{$\begin{array}{l}\text { Average body length } \\
(\mathrm{cm} / \text { fish })\end{array}$} & \multirow{2}{*}{ Gain (g/fish) } & \multirow{2}{*}{$\begin{array}{l}\text { ADG } \\
\text { (g/fish) }\end{array}$} & \multirow{2}{*}{ SGR (\%/day) } & \multirow{2}{*}{ RGR (\%) } & \multirow{2}{*}{ Survival (\%) } \\
\hline & IBW & FBW & IFL & $\mathrm{FF}$ & & & & & \\
\hline 50 & $9.16 \pm 0.00$ & $141.93 \pm 0.10^{\mathrm{a}}$ & $9.22 \pm 0.02$ & $24.70 \pm 0.07^{\mathrm{a}}$ & $132.7 \pm 0.1^{\mathrm{a}}$ & $1.90 \pm 0.00$ & $3.91 \pm 0.0^{\mathrm{a}}$ & $3.91 \pm 0.0^{\mathrm{a}}$ & $1549.21 \pm 1.4^{\mathrm{a}}$ \\
\hline 150 & $9.14 \pm 0.02$ & $107.85 \pm 0.21^{\mathrm{b}}$ & $9.19 \pm 0.02$ & $20.04 \pm 0.09^{b}$ & $98.7 \pm 0.2^{\mathrm{b}}$ & $1.41 \pm 0.00$ & $3.52 \pm 0.0^{\mathrm{b}}$ & $3.52 \pm 0.0^{\mathrm{b}}$ & $1180.03 \pm 1.2^{\mathrm{b}}$ \\
\hline 250 & $9.11 \pm 0.03$ & $88.17 \pm 0.12^{c}$ & $9.22 \pm 0.02$ & $18.54 \pm 0.06^{\mathrm{c}}$ & $79.1 \pm 0.1^{\mathrm{c}}$ & $1.13 \pm 0.00$ & $3.24 \pm 0.0^{c}$ & $3.24 \pm 0.0$ & $967.55 \pm 2.1^{\mathrm{c}}$ \\
\hline MSE & 0.000477 & 0.02490 & 0.000555 & 0.00638 & 0.019089 & 0.001 & 0.0000333 & 2.6295 & 0.71927 \\
\hline
\end{tabular}

Values are mean \pm Standard deviation. ${ }^{*}=(\mathrm{P} \leq 0.05){ }^{* *}=(\mathrm{P} \leq 0.01)$. Values in the same column with same superscripts are not significantly different. IBW = initial body weight; FBW = Final body weight. Gain (g/fish) = FBW-IBW; ADG = FBW-IBW/experimental period; SGR $(\% /$ day $)($ specific growth rate) $=$ (In FBW/In IBW)/time days). 
Table 3. Effect of different stoking density on feed utilization of Meagre (Argyrosomus regius, Asso1801).

\begin{tabular}{|c|c|c|c|c|c|c|c|c|}
\hline $\begin{array}{l}\text { Stoking } \\
\text { density }\end{array}$ & $\begin{array}{l}\text { Condition } \\
\text { factor }(\mathrm{K})\end{array}$ & $\begin{array}{l}\text { Feed intake } \\
\text { (g/fish) }\end{array}$ & FCR & PER & PPV (\%) & $\begin{array}{l}\text { Energy gain } \\
\quad(\text { Kcal })\end{array}$ & $\begin{array}{l}\text { Energy utilization } \\
(\mathrm{kcal} / 100 \mathrm{~g}\end{array}$ & $\begin{array}{c}\text { Total production } \\
\text { (kg/cage) }\end{array}$ \\
\hline 50 & $0.94 \pm 0.01^{\mathrm{c}}$ & $247.00 \pm 0.67^{\mathrm{c}}$ & $1.86 \pm 0.00^{c}$ & $1.26 \pm 0.00^{\mathrm{a}}$ & $32.44 \pm 0.06^{\mathrm{a}}$ & $288.37 \pm 0.20^{\mathrm{a}}$ & $22.17 \pm 0.04^{\mathrm{a}}$ & $109.0 \pm 0.1$ \\
\hline 150 & $1.34 \pm 0.01^{\mathrm{b}}$ & $254.89 \pm 0.19^{b}$ & $2.58 \pm 0.00^{\mathrm{b}}$ & $0.90 \pm 0.00^{\mathrm{b}}$ & $23.68 \pm 0.06^{\mathrm{b}}$ & $217.46 \pm 0.44^{\mathrm{b}}$ & $16.20 \pm 0.04^{\mathrm{b}}$ & $169.4 \pm 0.3$ \\
\hline 250 & $1.38 \pm 0.01^{\mathrm{a}}$ & $282.55 \pm 1.26^{\mathrm{a}}$ & $3.57 \pm 0.01^{\mathrm{a}}$ & $0.65 \pm 0.00^{c}$ & $17.32 \pm 0.06^{c}$ & $176.53 \pm 0.23^{c}$ & $11.86 \pm 0.04^{\mathrm{c}}$ & $171.5 \pm 0.2$ \\
\hline F & $848.89^{* *}$ & $1512.39^{\star *}$ & $24968.4^{* *}$ & $12405.5^{* *}$ & $40455.6^{* *}$ & $97378.8^{* *}$ & 39534.2 & \\
\hline MSE & 0.000211 & 0.69161 & 0.000088 & 0.000022 & 0.0042778 & 0.09866 & 0.002033 & \\
\hline
\end{tabular}

Values are mean \pm Standard deviation. ${ }^{*}=(\mathrm{P} \leq 0.05)^{* *}=(\mathrm{P} \leq 0.01)$. Values in the same column with same superscripts are not significantly different. Feed conversion ratio $(\mathrm{FCR})=$ Feed intake/Weight gain; Protein efficiency ratio $(\mathrm{PER})=$ Weight gain/Protein intake; Protein productive value $(\mathrm{PPV})=$ Protein gain/Protein intake; Energy utilization $=100 \times$ energy content of carcass at end-energy content of carcass at start/energy intake. Values in the same column with same superscripts are not significantly different. Feed conversion ratio (FCR) = Feed intake/Weight gain; Protein.

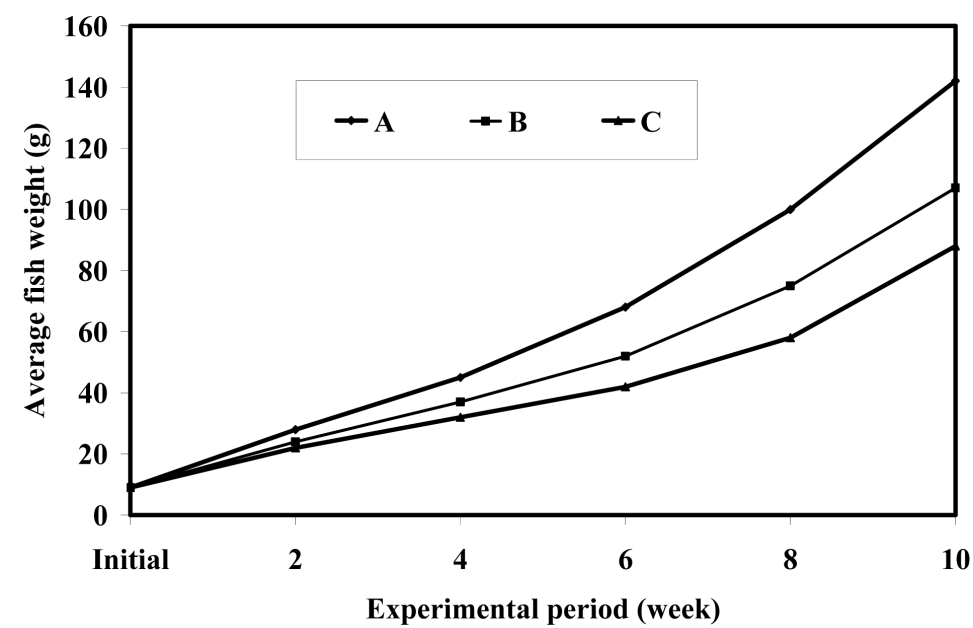

Figure 1. Effect of different stocking density on growth rate of Meagre (Argyrosomus regius, Asso1801).

are presented in Table 4. Feed utilization parameters were significantly $(\mathrm{P} \leq$ 0.01 ) affected by stocking density.

\subsection{Body Composition}

Moisture, protein, fat and ash contents of fish body of Meagre reared at three stocking density are presented in Table 4. Moisture content was high (62.3\%) at low stocking density and low (64.1\%) at the highest stocking density. Also, protein content and ash content showed the same trend as above.

\subsection{Economics}

The economic information for Meagre reared in cages for 10 weeks at three stocking density are presented in Table 5. From this table the net profits were directly related to stocking density. Also, the food cost and total cost increased by increasing stocking density. From the economic information, it can be concluded that the highest net profit was achieved at stocking density of $150 \mathrm{fish} / \mathrm{m}^{3}$ in cages. 

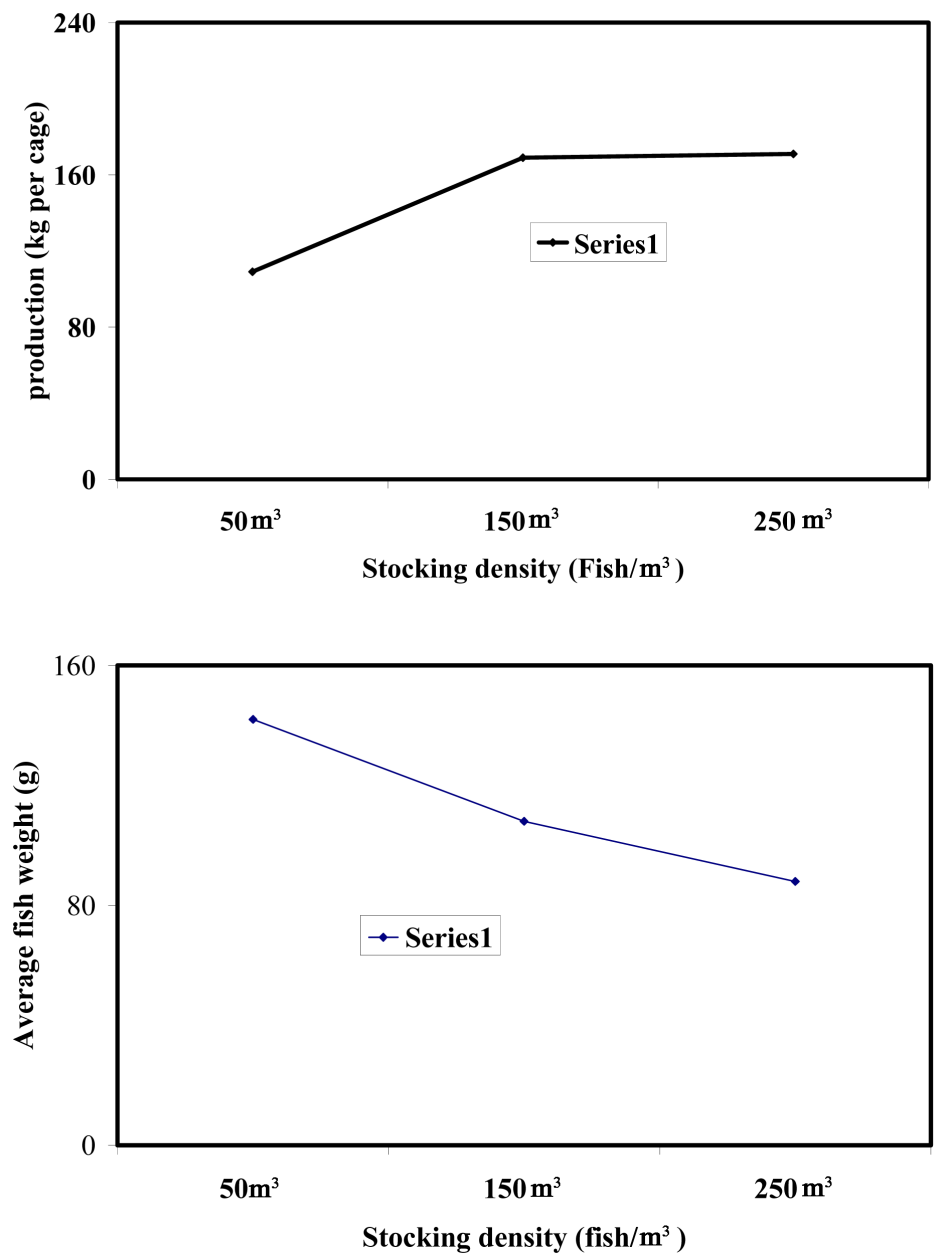

Figure 2. The relation between total production and stocking density (upper graph). The relation between final average weight per fish and stocking density (lower graph).

Table 4. Effect of stocking density on body composition (dry weight basis) of Meagre (Argyrosomus regius, Asso1801).

\begin{tabular}{cccccc}
\hline $\begin{array}{c}\text { Stocking } \\
\text { density }\end{array}$ & $\begin{array}{c}\text { Carcass energy } \\
(\mathrm{kcal} / 100 \mathrm{~g})\end{array}$ & $\begin{array}{c}\text { Moisture } \\
(\%)\end{array}$ & $\begin{array}{c}\text { Protein } \\
(\%)\end{array}$ & $\begin{array}{c}\text { Ether extract } \\
(\%)\end{array}$ & $\begin{array}{c}\text { Ash } \\
(\%)\end{array}$ \\
\hline 50 & $553.99 \pm 2.52$ & $62.26 \pm 0.9^{\mathrm{a}}$ & $65.89 \pm 0.23^{\mathrm{a}}$ & $19.23 \pm 0.15^{\mathrm{a}}$ & $14.34 \pm 0.14^{\mathrm{a}}$ \\
150 & $555.07 \pm 4.13$ & $60.32 \pm 1.1^{\mathrm{b}}$ & $64.54 \pm 3.8^{\mathrm{b}}$ & $20.15 \pm 0.21^{\mathrm{b}}$ & $14.32 \pm 0.23^{\mathrm{a}}$ \\
250 & $560.18 \pm 4.17$ & $59.16 \pm 1.0^{\mathrm{b}}$ & $64.14 \pm 0.48^{\mathrm{b}}$ & $20.93 \pm 0.19^{\mathrm{b}}$ & $13.54 \pm 0.17^{\mathrm{b}}$ \\
F & $2.4 \mathrm{NS}$ & $7.38^{\star *}$ & $20.25^{\star *}$ & $63.46^{* *}$ & $20.23^{\star *}$ \\
MSE & 13.6 & 0.999 & 0.125 & 0.034 & 0.309 \\
\hline
\end{tabular}

Values are mean \pm Standard deviation. ${ }^{*}=(\mathrm{P} \leq 0.05){ }^{* *}=(\mathrm{P} \leq 0.01)$. Values in the same column with same superscripts are not significantly different. The value of initial body composition was as follows: moisture $83.97 \pm 0.4$, protein $66.68 \pm 0.47$, ether extract $10.8 \pm 0.28$, ash $15.06 \pm 0.32$.

\section{Discussion}

As stocking density increases competition for food and living space increased and usually intensifies providing one of the most effective controls on animal production [14]. The effects of density may be divided into two categories: the 
Table 5. Economic information for Meagre (Argyrosomus regius) at three stocking density.

\begin{tabular}{cccc}
\hline & \multicolumn{3}{c}{ Stocking density } \\
\cline { 2 - 4 } Item & 50 & 150 & 250 \\
\hline No. fish stocked cage ${ }^{-1}$ & 1200 & 3600 & 6000 \\
No. fish harvested cage ${ }^{-1}$ & 768 & 1570 & 1944 \\
Harvested (kg/cage) & 109.0 & 169.2 & 171.5 \\
Food used Kg cage ${ }^{-1}$ & 189.7 & 400.2 & 549.4 \\
Fingerling cost(LE) & 400 & 1200 & 2000 \\
Food cost (LE) & 758.8 & 1600.8 & 2197.6 \\
Total cost (LE) & 1158.8 & 2800.8 & 4197.6 \\
Value of harvest (50LEkg & 5450 & 8460 & 8575 \\
Net profit (LE) & 4291.2 & 5659.2 & 4377.7 \\
\hline
\end{tabular}

Value are mean \pm SD LE = lever Egyptian one \$ US Dollar equal 17.65 LE. Food cost equal 4 LE/kg of diet.

density dependent and the density independent. The stocking density that significantly negatively affects the growth of fish was considered as density dependent category, such as the cases found for blue gill, Lepomis mar crochius Rafinesque [15], Chinook salmon, Oncorhynchus tshawytscha [16], Nile tilapia, Oreochromis niloticus [2]. In the present study the similar case of negative curvilinear relationship was found

[17] found that higher stocking density was accompanied by lower $\mathrm{pH}$ and dissolved oxygen and suggested that the resulting changes in water quality might play an important role in affecting growth and survival of fish. [18] indicated that metabolic wastes are directly proportional to stocking density have been implicated in inhibiting the growth of fish and to be toxic to fish. Moreover, fish need oxygen for aerobic generation of energy for body maintenance, locomotion, feeding and biosynthesis. A minimum dissolved oxygen level of $3.0 \mathrm{ppm}$ was recommended during cage culture of tilapia in freshwater [19]. In the present study, a minimum dissolved oxygen level was maintained above 4.3 $\mathrm{mg} / \mathrm{L}$ and no significant differences among the cages and no effected on growth was observed. The water flow system in the present study provided fairly good water quality consistently throughout the experimental period at all cages. There were no evidences of large physiochemical fluctuation, occurrence of diseases and handling stress, and deterioration of water quality in experimental cages during course of the experiment.

Beside water quality, the effect of stocking density on meagre fingerlings might be dependent upon the biological characteristics of fish, such as tolerance to environmental change, life stage, sex, social interaction and behavior, so that density effect on growth and production might be explained by their competition for territories [20]. The stress on fish caused by crowdedness may be other explanation for the effect of stocking density. [21], also found that high stocking densities of Silver pompano could induce stress and cause growth inhibition since silver pompano are extremely active fish. Lower stocking densities are suf- 
ficient to prove the technical viability of rearing pompano in marine floating cages. In our experiment, the highest biomass was achieved at stocking density $150 \mathrm{fish} / \mathrm{m}^{3}$.

Increased stocking densities caused reductions in survival rate of meagre (Table 5). Percent survival was significantly higher $(P<0.001)$ in fish reared at the lowest density level than in fish reared at either of the two higher densities. The difference in survival between groups of fish reared at the two highest densities was significant. Raceway loading (biomass per unit of water flow) also had apparent effect on survival of fish. Survival was greater in the $50 \mathrm{fish} / \mathrm{m}^{3}$ than in the $150 \mathrm{fish} / \mathrm{m}^{3}(\mathrm{P}<0.001)$.

Studies on higher stocking densities had been conducted in cage culture of other fish species, such as sea bass [22], salmonids [23], Japanese flounder [24] and red sea bream [25]. Fish reared at higher stocking densities had lowest final mean weight. [26] reported that slow growth of fish at higher stocking densities was probably due to the individual disturbing each other during feeding and normal activity.

In this study, the FCR (1.86) is quite similar to that reported by [27] with an FCR value of 1.84, but better than those reported by [28] from 2.51 to 2.59, [29] with FCR value of 3.0 and [30] with 2.13 and 2.23 with pompano. The decreasing values of feed conversion ratio obtained in this study with lower stocking density indicate that progressively larger portion of food was used for growth and fish assimilated the feed consumed more efficiently at lower stocking density.

There was a strong trend for both production and final harvest to increase with increasing stocking density. These results are in agreement with those of [31] from studies on Silver Pompano, Trachinotus blochii, (Lacépède, 1801) in marine floating cages. Also, [32] reported that reproduction of fish culture is generally depended on the stocking density.

Finally, it can be concluded that, the best desirable stocking density was 150 fish $/ \mathrm{m}^{3}$ which gave the highest production and economically had the highest net profit.

\section{Conflicts of Interest}

The authors declare no conflicts of interest regarding the publication of this paper.

\section{References}

[1] Duncan, N.J., Estévez, A. and Fernández-Palacios, H. (2013) Aquaculture Production of Meagre (Argyrosomus regius): Hatchery Techniques, on Growing and Market. In: Allan, G. and Burnell, G., Eds., Advances in Aquaculture Hatchery Technology, Wood Head Publishing Limited, 519-541.

https://doi.org/10.1533/9780857097460.3.519

[2] Grigorakis, K., Fountoulaki, E., Vasilaki, A., Mittakos, I. and Nathanailides, C. (2011) Lipid Quality and Filleting Yield of Reared Meagre (Argyrosomus regius). 
International Journal of Food Science Technology, 46, 711-716. https://doi.org/10.1111/j.1365-2621.2010.02537.x

[3] Maragoudaki, D., Paspais, M. and Kentouri, M. (1999) Influence of Stocking Density of Juvenile Red Porgy (Pagrus pagrus) under Different Feeding Conditions. Aquaculture Research, 30, 501-508. https://doi.org/10.1046/j.1365-2109.1999.00363.x

[4] El-Saidy, D.M.S. and Gaber, M.M. (2002) Intensive Culture of Nile tilapia, Oreochromis niloticus (L), in Concrete Tanks in Egypt: Effect of Stocking and Feeding Levels on Growth Performance, Production Traits, Feed Conversion and Body Composition. First Scientific Conference of the Egyptian Aquaculture Society, Organized by Faculty of Environmental Agriculture Sciences, Suez Canal University, El-Arish-North Sinai, Egypt.

[5] Leatherland, J.F. and Cho, C.Y. (1985) Effect of Rearing Density on Thyroid and Internal Gland Activity and Plasma Hepatic Metabolite Levels in Rainbow Trout, Salmo gairdneri, Richardson, Journal Fish. Biology, 27, 583-592.

https://doi.org/10.1111/j.1095-8649.1985.tb03203.x

[6] Khattab, Y.A.E., Abdel-Tawwab, M. and Ahmad, M.H. (2004) Effect of Protein Level and Stocking Density on Growth Performance, Survival Rate, Feed Utilization and Body Composition of Nile tilapia Fry (Oreochromis niloticus L.). In: Bolivar, R.B., Mair, G.C. and Fitzsimmons, K., Eds., New Dimension in Farmed Tilapia. Proceedings of the Sixth International Symposium on Tilapia in Aquaculture, Manila, Philippines, 1, 264-276.

[7] Malik, A., Kalhoro, H., Shah, S.A. and Kalhoro, I.B. (2014) The Effect of Different Stocking Densities on Growth, Production and Survival Rate of Pangas (Pangasius hypophthalmus) Fish in Cemented Tanks at Fish Hatchery Chilya Thatta, Sindh-Pakistan. International Journal of Interdisciplinary and Multidisciplinary Studies (IJIMS), 1, 129-136.

[8] Ellis, T., North, B., Scott, A.P., Bromage, N.R., Porter, M. and Gadd, D. (2002) The Relationships between Stocking Density and Welfare in Farmed Rainbow Trout. Journal of Fish Biology, 61, 493-531. https://doi.org/10.1111/j.1095-8649.2002.tb00893.x

[9] Golterman, H.L., Clymo, R.S. and Ohnstad, M.A.M. (1978) Methods of Physical and Chemical Analysis of Fresh Waters. Blackwell Scientific Publications, Oxford, 214 p.

[10] AOAC (Association of Official Analytical Chemists) (2006) Official Methods of Analysis. Horwitz, W., Ed. 18th Edition, Washington DC.

[11] Statistical Analysis System (1993) SAS/STAT User's Guide Release 6.03 Edition. SAS Institute Inc., Cary, North Carolina.

[12] Duncan, D.B. (1955) Multiple Range and Multiple F Tests. Biometrics, 11, 1-42. https://doi.org/10.2307/3001478

[13] Zar, J.H. (1984) Biostatistician Analysis. Prentice Hall, Englewood Cliffs, New Jersey.

[14] Huang, W.B. and Chiu, T.S. (1997) Effects of Stocking Density on Survival, Growth, Size Variation, and Production of Tilapia Fry. Aquaculture Research, 28,165-173. https://doi.org/10.1111/j.1365-2109.1997.tb01029.x

[15] Wiener, J.G. and Hanneman, W.R. (1982) Growth and Condition of Bluegills in Wisconsin Lakes: Effects of Population Density and Lake pH. Transactions of the American Fisheries Society, 111, 761-767. https://doi.org/10.1577/1548-8659(1982)111<761:GACOBI>2.0.CO;2 
[16] Martin, R.M. and Wertheimer, A. (1989) Adult Production of Chinook Salmon Reared at Different Densities and Released as Two Smolt Sizes. Progressive Fish-Culturist, 51, 194-200. https://doi.org/10.1577/1548-8640(1989)051<0194:APOCSR>2.3.CO;2

[17] Miao, S. (1992) Growth and Survival Model of Redtail Shrimp Penaeus pencillatus (Alock) According to Manipulating Stocking Density. Bulletin of the Institute of Zoology Academia, 31, 1-8.

[18] Chen, Y.S., Beveridge, M.C.M. and Telfer, T.C. (1999) Settling Rate Characteristics and Nutrient Content of the Faeces of Atlantic salmon, Salmo salar L. and the Implications for Modeling of Solid Waste Dispersion. Aquaculture Research, 30, 395-398. https://doi.org/10.1046/j.1365-2109.1999.00334.x

[19] Coche, A.G. (1982) Cage Culture of Tilapias. In: Pullin, R.S.V. and Lowe-McConnell, R.H., Eds., The Biology and Culture of Tilapias, ICLARM Conference Proceedings 7. International Center for Living Aquatic Resources Management, Manila, Philippines, 205-246.

[20] Gil, M.M., Palmer, M., Hernández, M.D., Grau, A., Durán, J., García García, B., Jover, M. and Pastor, E. (2015) Rearing Diet May Determine Fish Restocking Success: A Case Study of Hatchery-Reared Juvenile Meagre. Argyrosomus regius. Sci. Mar., 79, 431-441. https://doi.org/10.3989/scimar.04140.05A

[21] Chavez, H.M., Fang, A.L. and Carandang, A.A. (2011) Effect of Stocking Density on Growth Performance, Survival and Production of Silver Pompano, Trachinotus blochii, (Lacépède, 1801) in Marine Cages. Asian Fisheries. Science, 24, 321-330.

[22] Kissil, G.W., Tandler, A., Colorni, A. and Elizur, A. (2000) Sea Bass Culture. In: Stickney, R.R., Ed., Encyclopedia of Aquaculture, John Wiley and Sons Inc., New York, 778-784.

[23] Roberts, R.J. and Hardy, R.W. (2000) Salmon Culture. In: Stickney, R.R., Ed., Encyclopedia of Aquaculture, John Wiley and Sons Inc., New York, 773-778.

[24] Min, B.S. (1995) A Review of the Nursery and Grow-Out Culture Techniques for Flounder (Paralichtys olivaceus) in Korea. In: Main, K.L. and Rosenfeld, C., Eds., Culture of High-Value Marine Finfish in Asia and the United States, The Oceanic Institute, Honolulu, Hawaii, 147-152.

[25] Ikenoue, H. and Kofuku, T. (1992) Mode Methods of Aquaculture in Japan. Elsevier, Amsterdam, $274 \mathrm{p}$.

[26] Hepher, B., Milstein, A., Leventer, H. and Teltsch, B. (1989) The Effect of Fish Density and Species Combination on Growth and Utilization of Natural Food in Ponds. Aquaculture and Fisheries Management, 20, 59-71. https://doi.org/10.1111/j.1365-2109.1989.tb00441.x

[27] Manomaitis, L. and Cremer, C.M. (2007) Performance of Pompano Fed Soy-Optimized, Extruded Feed Using ASA-IM Low Volume High Density Cages in Vung Tau Province, Vietnam. Results of ASA-IM/Soy-in-Aquaculture 2007, Feeding Demonstration Project. American Soybean International Marketing (ASA-IM).

[28] Lan, H.P., Cremer, M.C., Chappell, J., Hawke, J. and O’Keefe, T. (2007) Growth performance of Pompano (Trachinotus blochii) Fed Fishmeal and Soy Based Diets in Offshore OCAT Ocean Cages. Results of the 2007 OCAT Cage Feeding Trial in Hainan, China.

[29] McMaster, M.F., Kloth, T.C., Coburn, J.F. and Stolpe, N.E. (2006) Florida Pompano Trachinotus carolinus Is an Alternative Species for Low Salinity Shrimp Pond Farming. In: Aquaculture America 2006. Mariculture Technologies International Inc. 
[30] Cremer, M.C. and Jian, Z. (1999) Pompano (Trachinotus ovatus) Growth Performance in $1.5 \mathrm{~m}^{3}$ Cages with Soybean Meal and Fish Meal Based Feed Rations. Results of ASA/China, 1999. Feeding Trial, 35, 99-73.

[31] Chavez, H.M., Fang, A.L. and Carandang, A.A. (2011) Effect of Stocking Density on Growth Performance, Survival and Production of Silver Pompano, Trachinotus blochii, (Lacépède, 1801) in Marine Cages. Asian Fish. Sci., 24, 321-330.

[32] Kayano, Y., Yao, S., Yamamoto, S. and Nakagawa, H. (1993) Effect of Feeding Frequency on the Growth and Body Constituents of Young Red-Spotted Group Eplnephelus akaara. Aquaculture, 110, 271-278. https://doi.org/10.1016/0044-8486(93)90375-9

[33] Madan, M., Bhanja, S.K. and Yasmeen, B. (2009) Performance of Chitin Incorporated Diet on the Indigenous Kumaon Himalayan Fishes: Snow Trout, Schizothorax richardsonii (Gray) and Golden Mahseer, Tor putitora (Hamilton). Indian J. Fish., 56, 135-137. 